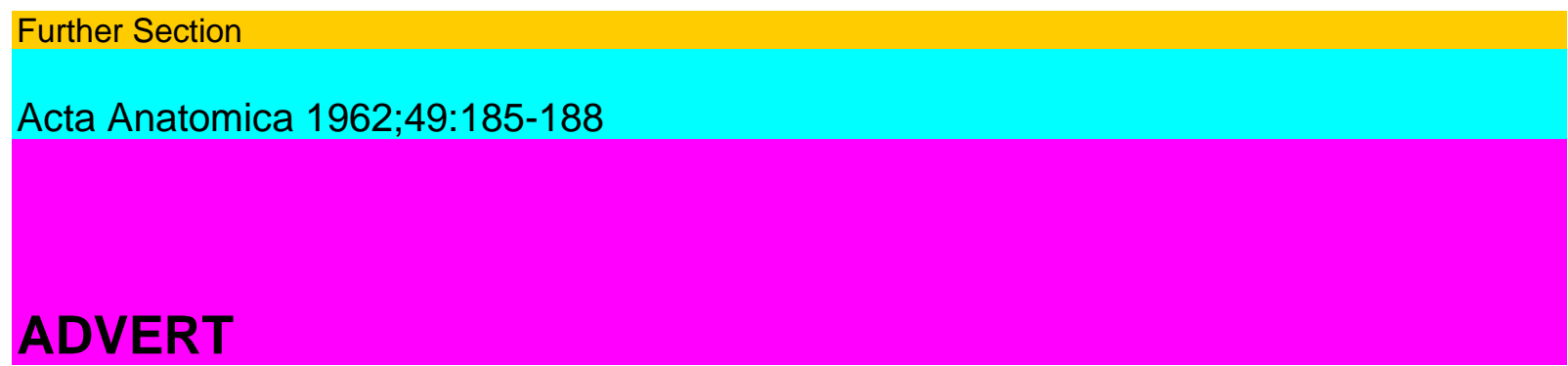

\title{
ALLGEMEINE BEDINGUNGEN
}

Die «Acta Anatomica» erscheinen in Heften von ca. ioo Seiten. 4 Hefte bilden einen Band zum Abonnementspreis von sFr. 77.- plus Porto. In der Zeitschrift werden veröfFentlicht:

Originalarbeiten aus alien Teil- und Grenzgebieten der Anatomie, Histologie, Embryologie und Zellforschung, deren Ergebnisse anderweitig noch nicht veröfFentlicht sind.

Übersichtsreferate über ausgewählte Gebiete sowie über die morphologische Literatur derjenigen Lander, deren Sprachen vielen Lesern der Zeitschrift schwerer zugänglich sind. Berichte über Tagungen der Anatomenvereinigungen verschiedener Lander. Personalien, Tagesberichte.

Publikationssprachen sind Deutsch, Englisch, Französisch. Jede Originalarbeit erhält eine Zusammenfassung der Ergebnisse in diesen drei Sprachen. Die Zusammenfassung ist möglichst kurz zu halten.

Die Mitarbeiter erhalten an Stelle eines Honorars 50 Sonderdrucke kostenfrei. Weitere Sonderdrucke, die bei der Rücksendung der ersten Korrektur zu bestellen sind, liefert der Verlag gegen Berechnung.

Die Autoren von Originalarbeiten werden um Berücksichtigung folgender Punkte gebeten:

Die Arbeiten sind in einer der drei Publikationssprachen in druckreifem Zustand einzureichen.

Die Arbeiten sind so kurz wie möglich zu fassen. Originalarbeiten, die 2 Bogen $=32$ Druckseiten überschreiten, können nur angenommen werden, wenn die Autoren für die Kosten des Mehrumfangs auf kommen.

Die fremdsprachigen Zusammenfassungen sind im Hinblick auf eine sinngetreue Über-setzung möglichst vom Autor zu besorgen.

Das Literaturverzeichnis ist den Anweisungen entsprechend zu verfassen, die von Zeit zu Zeit in dieser Zeitschrift veröfFentlicht werden.

Alle Manuskripte, Rezensionsexemplare und redaktionelle Zuschriften sind an einen der Redaktoren zu richten, hingegen Anfragen wegen Abonnements und Inseraten an den Verlag 5. Karger AG., Basel (Schweiz), Arnold-Böcklin-Strasse 25.

E.A. Boyden, Dept. of Anatomy, University of Washington, Seattle, Wash. (USA) A. Deímas, Institut d'Anatomie, Ecole de Médecine, Paris 6e (France) G. Glimstedt, Institutionen for Mikroskopisk Anatomi, Lund (Sverige) G. Wolf-Heidegger, Anatomisches Institut der Universität, Basel (Schweitל) RENSEIGNEMENTS GÉNÉRAUX

Les «Acta Anatomica» paraissent en fascicules d'environ 100 pages. Quatre fascicules forment un volume; le prix d'abonnement est de frs.s. 77.- (port inclus). La revue publie: des travaux originaux sur toutes les parties de $\Gamma$ anatomie normale, de l'histologie, de $\Gamma$ embryologie et de la cytologie expérimentale, ainsi que des domaines voisins, pour autant que leurs résultats n'aient pas été publiés déjà ailleurs;

des revues générales sur des sujets choisis, et des analyses de la littérature peu accessible aux lecteurs du périodique pour des raisons de langue; 
des comptes-rendus des reunions d'associations d'anatomistes de divers pays;

des informations personnelles, des nouvelles d'actualité.

Les langues de publications sont le français, l'anglais, Гallemand. Chaque travail original sera resume dans ces trois langues.

Les collaborateurs recevront 50 tirages-à-part gratuits à titre d'honoraire. Les tirages-à-part supplémentaires devront être commandos en retournant les premieres épreuves; ces tirages-à-part seront facturés à un prix special.

Les auteurs des travaux originaux sont pries de se tenir aux conditions suivantes:

Les travaux doivent nous être présentés dans $\Gamma$ une des trois langues publicitaires, prêts ainsi à être imprimés.

Les travaux doivent être aussi brefs que possible. Tout travail original dépassant deux feuilles $=$ 32 pages imprimées ne pourra être accepté que si l'auteur prend les frais supplémentaires à sa charge.

Les auteurs sont pries de fournir si possible eux-mêmes les resumes en langues étrangères.

Des indications détaillées pour la redaction des manuscrits se trouvent dans une annonce spéciale qui paraîtra de temps en temps dans cette Revue.

Les manuscrits, les livres dont on demande une analyse, ainsi que la correspondance ayant trait à la revue doivent être adressés à l'un des rédacteurs. Les épreuves, les demandes d'abonne-ments ou d'annonces seront par contre adressées à Гéditeur S. Karger, S.A., Bale (Suisse) ArnoldBöcklin-Strasse 25.

E.A. Boyden, Dept. of Anatomy, University of Washington, Seattle Wash. A. Delmas, Institut d'Anatomie, Ecole de Médecine, Paris 6e (France) Gösta Glimstedt, Institutionen for Mikroskopisk Anatomi, Lund (Sverige) Gerhard Wolf-Heidegger, Anatomisches Institut der Universität, Basel (Schwei·i?)

186

Rules for the Preparation of Manuscripts

Experience has shown that many authors do not realise how much trouble and additional costs could be avoided for themselves and for the publishers if manuscripts were prepared in accordance with the regulations set out below. To assist our authors in their task, a third revised edition of the "Rules for the Preparation of Manuscripts and Bibliographies with a List of Abbreviations of Titles of Current Medical Periodicals" has been published. This booklet can be obtained from the publishers, Messrs. S. Karger AG, Arnold-Böcklin-Strasse 25, Basel (Switzerland) against payment of S.Frs. 2.50, or 5 International Reply Coupons. The most important points from these rules are the following:

Manuscripts must be submitted ready for print, typewritten on one side of the paper only and double spaced.

Indication of Institute. At the top of the first page, the name of the Institute where the author has conducted his research work must be indicated in the language of the paper.

Title. The main title of the paper must be underlined and possible subtitles indicated as such. Small type. Paragraphs which can or must be set in smaller type (case histories, chemical laboratory test methods, etc.) should be indicated with a "P" (petit) in the margin on the left-hand side.

Surnames in the text are to be written in capitals: MILLER (1945) and MYERS (1953). If there are two or more authors to a paper, the word "and" should also be written in capitals: SMITH AND BROWN (1957). 
Accentuation. Single words or whole sentences to be stressed should be underlined, they will be set in italics.

Footnotes should appear at the bottom of the respective page.

Illustrations should be numbered in Arabic and must have a legend. For the preparation of blocks good drawings and original photographs should be submitted; negatives cannot be used. If possible, several illustrations should be grouped for reproduction on one block (max. size ii $\times$ i $\delta$ $\mathrm{cm})$. Illustrations and legends must be attached separately to the manuscript.

\section{Tî̂8}

Tables should be numbered in Roman numerals and must have a heading. They should be attached to the manuscript on a separate sheet.

Summary. Each paper must have a summary of not more than 10 lines.

References should include those publications only which are mentioned in the text. They must be arranged alphabetically according to authors' names. For extensive bibliographies numbering is indicated, the respective number to be quoted in the text in place of the author's name.

The following indications are necessary:

a) Papers published in Periodicals: 1. Authors'

surnames with initials of all Christian

names; 2 . full tide of paper; 3 . name of peri

odical abbreviated in accordance with the

international rules; 4 . number of volume

(in Arabic, underlined and followed by a

colon); 5. number of first and last page of

paper quoted; 6 . year of publication in

brackets:

COLLINS, P; MARSHALL, J. and SHAW, D. A.: Social rehabilitation following

cerebrovascular accidents. Geront. clin. 2 : 246-256 (i960).

b) Books: 1. Authors' surnames with initials

of Christian names; 2. full tide of book;

3. in brackets name and domicile of pub

lishers and year of publication:

BANGERTER, A.: Amblyopiebehandlung. 2nd ed.

(Karger, Basel/New York 1955).

Full address. At the end of each manuscript the exact address of all authors should be given. 187

Directives sur la redaction d'un manuscrit

L'expérience permet de constater que de nombreux auteurs ignorent qu'ils pourraient éviter certaines difficultés de même que des frais supplémentaires pour correction, aux rédacteurs et éditeurs en se conformant aux regies suivantes. Dans ce but, nous venons de publier la troisième edition de la brochure «Directives sur la Redaction d'un Manuscrit et $\Gamma$ Etablissement d'une Bibliographic avec une liste des Abréviations des Périodiques médicaux les plus courants » qui peut être obtenue aux Editions S. Karger S.A. Bale contre 5 coupons internationaux ou paiement de fr.s. 2.50. Les points suivants font $\Gamma$ objet de cette brochure.

Manuscrits: Les manuscrits doivent être remis prêts à la composition, dactylographies au double interligne, sur un seul côté de page.

Origine du travail: Indiquer Tinstitut d'où provient le travail en tête de la premiere page.

Titre du travail: Mettre le titre en evidence en le soulignant; il faut le différencier des sous-titres. 
Petits caractères: Tout ce qui peut ou doit être imprimé en petits caractères (par exemple: Remarques de malades, méthodes de recherches chimiques dans un laboratoire, etc.) doit être indiqué en marge par un P.

Noms propres: Ils doivent être en majuscules: DUNAND (1945) et MALLET (1953). Lorsqu'il s'agit de deux auteurs, la conjonction, elle aussi, sera écrite en majuscules: FABRE ET FRONSAC (1957).

Composition en caractères différents:

Souligner les mots ou les phrases qui doivent être mis en evidence; ils seront composes en italiques.

Notes: sont à inscrire au bas des pages cor-respondantes du manuscrit.

Tableaux: Numéroter les tableaux en chirTres romains qui pour simplifier seront remis en annexe du manuscrit.

Illustrations: Elles doivent être numé-rotées en chiífres arabes, et doivent être ac-compagnées d'une légende. Pour le clichage, les dessins originaux sont préférables aux copies

photogtaphiques et dessins. Les négatifs

Tiii

ne sont pas desires. II est sou vent avantageux de réunir plusieurs illustrations en un cliche (grandeur max. $11 \times 18 \mathrm{~cm}$ ). Les documents et les légendes doivent nous être remis séparément. Resume: Joindre un resume à chaque travail. Celui-ci ne doit pas dépasser 10 lignes.

Bibliographic: La bibliographic ne doit contenir que les travaux des auteurs cites, présentés par ordre alphabétique. Lorsque les citations sont nombreuses, il est opportun de les numéroter, afin de gagner de la place, les numéros étant utilises pour les citations dans le texte.

a) Pour les périodiques: Si un article a plusieurs

auteurs, les initiales du prénom du deuxième

auteur et des suivants doivent suivre le nom

de famille. Titre complet de $\Gamma$ article. Titre

du périodique abrégé d'après nos directives.

Numéro du volume du périodique (chiffres

arabes et souligné) suivi de deux points (:).

Numéro de la premiere et dernière page du

travail. Année de publication (entre paren

theses).

COLLINS, P; MARSHALL, J. and SHAW, D.A.: Social rehabilitation following

cerebrovascular accidents. Geront. clin. 2: 246-256 (1960).

b) Pour les livres: Si un ouvrage a été rédigé

par plusieurs auteurs, les initiales du prénom

du deuxième auteur et des suivants doivent

suivre le nom de famille. Titre complet de la

publication. Nom de $\Gamma$ éditeur, lieu et année

de parution entre parentheses.

BAMATTER, F. : Urologie infantile (Karger, Basel/

New York 1961).

Adresse exacte: II est nécessaire d'indi-quer à la fin du travail Гadresse exacte de tous les auteurs.

188

Regeln zur Abfassung eines Manuskrïptes 
Die Erfahrung zeigt, dass viele Autoren sich kaum bewusst sind, wieviel Mühe und oft sogar zusätzliche Korrekturkosten sie sich, dem Redaktor und demVerleger ersparen könnten, wenn sie bei der Abfassung ihrer Manuskripte die nachfolgendenVorschriften beachten würden. Um unseren Autoren die endgültige Abschrift einer Arbeit zu erleichtern, haben wir in dritter, verbesserter Auflage eine « Kurze Anleitung zur Abfassung von Manuskript und Literaturverzeichnis mit einer Liste der abgekürzten Zeitschriftentitel der meist zitierten medizinischen Periodica» herausge-geben. Sie kann gegen Einsendung von 5 internationalen Antwortscheinen oder Fr. 2.50 beim Verlag S. Karger, Arnold-Böcklin-Strasse 25, Basel, bezogen werden. Die wichtigsten Punkte daraus sind hier festgehalten.

Manuskripte sind in druckreifem Zustand einzureichen, einseitig mit Maschine und in doppeltem Zeiknabstand geschrieben.

Institutsanabe. Am Kopf der ersten Seite ist in der Sprache der Arbeit das Institut anzugeben, aus dem die Arbeit hervorge-gangen ist.

Tit $\beta 1$ der Arbeit. Der Titel ist durch Un-terstreichung hervorzuheben und von all-fälligen Untertiteln zu unterscheiden.

Kieindruck. Was kleiner gedruckt werden kann oder soil (Krankengeschichten, chemi-sche Untersuchungsmethoden im Labor usw.) muss am linken Rande mit einem grossen P als «Petitsatz » bezeichnet werden.

Eigennamen sind im Text in Versalien zu schreiben: MÜLLER (1945) und MAYER (1953). Bei Doppelautoren ist auch das Bindewort in Versalien zu schreiben: HEID UND ZIMMERMANN (1957).

Auszeichnungen. Einzelne Wörter und ganze Sätze, die hervorgehoben werden sollen, sind zu unterstreichen, damit sie kursiv gesetzt werden.

Fussnoten schreibe man unten auf die ent-sprechende Manuskriptseite.

Tabellen. Diese werden römisch numeriert und benötigen eine Überschrift. Die Tabellen legt man am einfachsten dem Manuskript separat bei.

Abbïldungen sollen arabiscb numeriert werden und benötigen auf jeden Fall eine Legende. Als Vorlagen für Klischees genü-gen nur sehr gute Zeichnungen oder Photo-graphien. Meistens sind nur Originale gut genug; Negative sind nicht erwünscht.

$\mathrm{T} \mathrm{i} \beta \mathrm{j}$

Wenn möglich sind Einzelbilder zu Blöcken zusammenzustellen (max. Grösse $11 \times 18 \mathrm{~cm}$ ). Man gebe die Vorlagen und die Legenden getrennt dem Manuskript bei.

Zusammenfassung. Jeder Arbeit muss eine Zusammenfassung beigegeben werden, die eine Länge von 10 Zeilen nicht über-schreiten darf.

Das Literaturverzeichnis soil nur die im Text zitierten Publikationen enthalten. Diese sind nach den Autorennamen alpha-betisch zu ordnen.

Bei einer grösseren Zahl von Zitaten ist aus Gründen der Platzersparnis ausserdem eine fortlaufende Numerierung erwünscht, welche gleichzeitig zur Zitierung im Text verwendet wird. a) Zeitschriftenbeiträge: 1. Sämtliche Autoren namen, gefolgt von den Initialen der Vorna-

men; 2. vollständiger Titel der Arbeit; 3 . nach den internationalen Regeln abgekürzter Titel der Zeitschrift; 4. Bandzahl der Zeitschrift (immer in arabischen Ziffern wiedergegeben, einmal unterstrichen und gefolgt von einem Doppelpunkt); 5. die erste und letzte Seiten- 
zahl der Arbeit; 6. in Klammern das Erscheinungsjahr.

COLLINS, P.; MARSHALL, J. and SHAW, D. A.: Social rehabilitation following cerebrovascular accidents. Gcront. clin. 2: 246-256 (i960).

b) Biicher: 1. Sämtliche Autorennamen, ge

folgt von den Initialen der Vornamen;

2. vollständiger Buchtitel; 3. in Klammern

der Verlag, Erscheinungsort und Erschei-

nungsjahr.

BANGERTER, A.: Amblyopiebehandlung. 2. Aufl. (Karger, Basel/New York 1955).

Genaue Adresse. Am Schluss der Arbeit ist die genaue Adresse aller Autoren anzugeben. 